\title{
PENGENALAN PRODUK MAKANAN DAN KOSMETIK BERBAHAN DASAR BUAH NAGA MERAH (HYLOCEREUS POLYRHIZUS) YANG KAYA ANTIOKSIDAN DAN BAIK BAGI KESEHATAN
}

\section{INTRODUCTION TO FOOD AND COSMETIC PRODUCTS BASED ON RED DRAGON FRUIT (HYLOCEREUS POLYRHIZUS) WHICH IS RICH ANTIOXIDANT AND GOOD FOR HEALTH}

\author{
Elfia Siska Yasa Putri ${ }^{\# 1}$, Vivi Anggia ${ }^{\# 2}$ \\ ${ }^{\#}$ Program Studi Farmasi, Universitas Muhammadiyah Prof DR Hamka, Islamic Center, Jalan Delima Raya \\ II/IV, Perumnas Klender, Jakarta Timur \\ ${ }^{1}$ elfia.siska@uhamka.ac.id \\ ${ }^{2}$ vivianggia@uhamka.ac.id
}

\begin{abstract}
Abstrak
Indonesia tengah menghadapi tantangan masalah kesehatan meningkatnya penyakit tidak menular (PTM) seperti stroke, penyakit jantung koroner (PJK), kanker dan diabetes justru menduduki peringkat tertinggi. Kurangnya kesadaran akan pola hidup dan makan yang sehat merupakan salah satu penyebab kondisi ini. Kecenderungan kehidupan masyarakat yang memilih segala sesuatunya serba instan termasuk dalam konsumsi makanan dan kosmetik yang saat ini banyak yang menggunakan bahan-bahan berbahaya termasuk pewarna menyebabkan banyak timbulnya penyakit. Begitu pula dengan kehidupan masyarakat pada lingkungan Kampung Jati, Desa Parung, Bogor. Pendekatan terpadu untuk merubah perilaku masyarakat agar mengkonsumsi makanan sehat yang akan memberikan dampak yang positif dimasa depan yang akan menurunkan PTM. Pada saat ini gaya hidup sehat atau kembali ke alam (back to nature) telah menjadi tren baru masyarakat. Konsumsi buah setiap hari memberikan banyak manfaat bagi tubuh kita, bukan saja rasanya yang enak tapi buah dan sayur kaya akan antioksidan yang bermanfaat untuk mencegah terjadinya stres oksidatif, sehingga pada pengabdian masyarakat ini kami mencoba memanfaatkan pigmen pada buah naga merah sebagai sumber antioksidan alami dan pewarna alami pada pembuatan produk makanan dan produk kosmetik sederhana. Dengan adanya kegiatan ini diharapkan peningkatan pemahaman dan pengetahuan tentang manfaat konsumsi buah naga merah dan cara pemanfaatan buah naga merah sebagai bahan dasar makanan dan kosmetik. Dengan meningkatnya pemahanam dan pengetahuan tersebut, diharapkan mampu menumbuhkan kesadaran untuk mengikuti gaya hidup sehat sehingga terhindar dari penyakit.
\end{abstract}

Kata Kunci — antioksidan, buah naga merah, kosmetik, makanan, penyakit tidak menular (PTM)

Abstract

Indonesia is facing the challenges of health problems increasing non-communicable diseases (PTM) such as stroke, coronary heart disease (CHD), cancer and diabetes are in the highest rank. Lack of awareness of a healthy lifestyle and eating is one of the causes of this condition. The tendency of people's lives to choose everything is instant, including the consumption of food and cosmetics, which currently use many hazardous substances, including dyes, which cause many diseases. Likewise with the community life in Kampung Jati, Parung Village, Bogor. An integrated approach to changing people's behavior to consume healthy foods which will have a positive impact in the future which will reduce PTM. Nowadays, a healthy lifestyle or back to nature has become a new trend in society. Consumption of fruit every day provides many benefits for our bodies, not only it tastes good but fruits and vegetables are rich in antioxidants which are useful for preventing oxidative stress, so that in this community service we tried to utilize the pigments in red dragon fruit as a source of natural antioxidants and dyes. natural at the manufacture of simple food and cosmetic products. With this activity, it is hoped that an increase in understanding and knowledge of the benefits of consuming red dragon fruit and how to use red dragon fruit as a basic ingredient for food and cosmetics. With the increased understanding and knowledge, it is hoped that it will be able to raise awareness to follow a healthy lifestyle so that it can avoid disease.

Keywords - antioxidants, red dragon fruit, cosmetics, food, non-communicable diseases (PTM) 


\section{PENDAHULUAN}

Indonesia tengah menghadapi tantangan besar yakni masalah kesehatan triple burden, karena masih adanya penyakit infeksi, meningkatnya penyakit tidak menular (PTM) dan penyakit-penyakit yang seharusnya sudah teratasi muncul kembali. WHO memperkirakan PTM (stroke, penyakit jantung koroner, kanker, diabetes, dan penyakit akibat gangguan metabolism) menyebabkan $56 \%$ dari semua kematian dan $44 \%$ dari beban penyakit dalam negara-negara di wilayah Asia Tenggara. Hampir setengah dari kematian PTM terjadi pada usia produktif dalam kehidupan (35-60 tahun) sehingga kondisi ini merupakan ancaman serius bagi tingkat sosial-ekonomi [1] masyarakat Kementrian Kesehatan, 2011. Di Indonesia, proporsi angka kematian PTM adalah 59,5 persen pada tahun 2007 (B. P. dan P. K. D. K. Republik Indonesia, 2008). Kondisi ini diperburuk dengan faktor resiko umum yang terkait dengan perilaku individu antara lain konsumsi makanan tidak sehat, kurangnya aktivitas fisik, merokok dan minum alkohol, serta menghirup udara yang terpolusi [1] Kementrian Kesehatan, 2011).

Kehidupan masyarakat pada lingkungan kampung Jati, Desa Parung, Bogor cenderung mengkonsumsi makanan serba instan dan kurang mengkonsumsi buah-buahan. Selain itu kebiasaan para wanita baik ibu-ibu atau remaja ingin tetap tampil cantik dengan jalan menggunakan kosmetik juga memperparah keadaan ini. Bahan Pewarna Merah K.3 (CI 15585), Merah K.10 (Rhodamin B) dan Jingga K.1 (CI 12075) sering disalahgunakan pada produk lipstik atau sediaan dekoratif lain (pemulas kelopak mata dan perona pipi), dietilen glikol dan timbal $(\mathrm{Pb})$. Padahal pemakaian bahan ini tidak sesuai dengan aturan Pemerintah mengenai penggunaan bahan kosmetik (B. P. O. D. M. Republik Indonesia, 2008). Dengan demikian, kebiasaan pola hidup tidak sehat ini akan memicu berbagai penyakit termasuk salah satunya PTM.

Untuk menurunkan prevalensi PTM maka banyak hal-hal penting yang harus diperhatikan. Gaya hidup sehat atau kembali ke alam (back to nature) telah menjadi tren baru masyarakat. Konsumsi buah dan sayur setiap hari memberikan banyak manfaat bagi tubuh kita, bukan saja rasanya yang enak tapi buah dan sayur kaya akan antioksidan yang bermanfaat untuk mencegah terjadinya stres oksidatif. Berbagai buah dan sayuran banyak yang mengandung antioksidan tapi pada sosialisasi ini kami membahas sumber antioksidan pada buah naga merah serta praktek pembuatan produk makanan atau jajanan serta kosmetik sederhana dari buah naga merah. Buah naga merah dengan nama latin Hylocereus polyrhizus dikenal dengan nama 'pitaya' di India. Banyak penelitian yang telah dilakukan untuk mengkaji khasiat buah naga merah untuk mengobati berbagai penyakit. (Omidizadeh et al., 2014) menemukan bahwa daging buah naga merah memberikan aktivitas yaitu mengurangi resistensi insulin pada penyakit diabetes, mengurangi hipertrigliseridemia dan aterosklerosis pada tikus yang diberi suplemen fruktosa. Ekstrak dan fraksi kulit buah naga merah memberikan aktivitas antibakteri yang potensial melawan berbagai bakteri patogen [2] M.M.A et al., 2012. Selain itu (Rebecca, Boyce and Chandran, 2010) menemukan bahwa pigmen pada buah naga merah mengandung polifenol memberikan aktivitas antioksidan yang baik sekali bagi tubuh dibandingkan dengan standar yaitu vitamin C. Antioksidan baik yang dikonsumsi ataupun yang digunakan diluar tubuh seperti produk kosmetik memberikan dampak yang baik bagi tubuh. Adanya senyawa antioksidan yang terkandung di dalam produk kosmetik akan membantu mengurangi efek-efek buruk dari berbagai poluten baik senyawa kimia ataupun dari sinar matahari. Sehingga pada pengabdian masyarakat ini kami mencoba memanfaatkan pigmen pada buah naga merah sebagai sumber antioksidan alami dan pewarna alami pada pembuatan produk makanan serta produk kosmetik sederhana yaitu praktek pembuatan produk kosmetik yaitu lipbalm dengan memanfaatkan pigmen pada buah naga merah untuk dibuat menjadi pewarna bahan dasar kosmetik..

\section{TARGET DAN LUARAN}

Pada masyarakat yang berkembang pola konsumsi makanan yang beragam, bergizi dan seimbang melalui pengolahan makanan secara tradisional telah bergeser menjadi pola konsumsi makanan cepat saji yang tinggi kadar lemak jenuh, tinggi garam dan gula tetapi kurang serat. Pemakaian kosmetik yang tidak sehat (mengandung pewarna yang tidak diizinkan BPOM) juga diminati masyarakat. Ternyata dengan adanya kemajuan ilmu pengetahuan teknologi yakni promosi 'junk food' dan 'cantik secara instan' yang sangat menarik melalui iklan diberbagai media massa mempengaruhi pola pikir ibu-ibu majelis ta'lim RT 004 RW 004 dan wali murid di TK/ Paud Raudhatul Athfal AnNashr Kampung Jati, Desa Parung. Diterapkannya perdagangan bebas sebagai adanya arus globalisasi sehingga makanan junk food dan fast food relatif murah yang terjangkau oleh masyarakat menyebabkan tingkat konsumsi makanan ini semakin tinggi. Perubahan gaya hidup ini menyebabkan datangnya berbagai penyakit, salah satunya

PTM. 
Untuk mengajak masyarakat mengikuti gaya hidup sehat maka diperkenalkan pemanfaatan buah naga merah yang kaya antioksidan pada olahan makanan, minuman dan kosmetik. Pada kegiatan pengabdian ini diharapkan meningkatkan pengetahuan mitra dan masyarakat umum tentang meningkatkan pemahaman dan pengetahuan tentang manfaat buah naga merah sebagai bahan yang mengandung antioksidan dan pewarna alami sehingga bisa diolah sedemikian rupa menjadi makanan dan minuman yang sehat dan kosmetik sederhana yang aman bagi tubuh. Manfaat lain yang dicapai dari program ini adalah membantu mitra untuk mengembangkan kemampuan dan ketrampilannya untuk memecahkan masalah yakni mengikuti gaya hidup sehat dengan memanfaatkan buah naga untuk dikonsumsi sebagai produk makanan dan minuman dan produk kosmetik. Para ibu-ibu diharapkan dapat menerapkannya pada kehidupan sehari-hari sehingga menjadi suatu usaha preventif dari terjangkitnya penyakit sekaligus meningkatkan derajat kesehatan keluarga. .

\section{METODE PELAKSANAAN}

Pelaksanaan program diawali dengan pengurusan izin dan kerja sama dengan Ketua RT 04 RW 04 di kampung Jati, Desa Parung, pendataan, penjaringan subyek (kelompok target), dan sosialisasi program di lokasi mitra pengabdian. Setelah itu, mitra yang terdiri dari ibu-ibu majelis ta'lim RT 004 RW 004 dan wali murid di TK/ Paud Raudhatul Athfal AnNashr Kampung Jati, Desa Parung, diminta kesediaannya untuk ikut berpartisipasi dan bekerja sama dalam program. Tahapan program kegiatan dimulai dengan memberikan edukasi dan penyuluhan tentang gejala gangguan kesehatan salah satunya PTM, memberikan penyuluhan dan edukasi cara mengatasinya dengan mengikuti mengikuti gaya hidup sehat, sesi diskusi setelah pemaparan dari Tim Dosen Fakultas Farmasi Dan Sains Universitas Muhammadiyah Prof.Dr.Hamka. Selanjutnya dilakukan edukasi tentang pengolahan buah naga sebagai bahan makanan, minuman dan kosmetik, pembagian booklet yang berisi tentang resep-resep makanan berbehan dasar buah naga merah serta cara pembuatan kosmetik lipbalm dari buah naga yang bisa dibuat oleh warga secara mandiri. Tahapan kegiatan berikutnya adalah praktek pembuataan puding buah naga merah, es buah naga merah, kosmetik lipbalm dengan metode sederhana serta diskusi yang terjadi antara narasumber dengan mitra. Tahap akhir di kegiatan ini adalah pembagian form pada warga dimana warga diminta untuk menuliskan kesan dan pesan dari acara yang dilaksanakan . Tabel 1 menjelaskan tahapan atau langkah-langkah dalam melaksanakan solusi yang ditawarkan untuk mengatasi permasalahan.
TABEL I

TAHAPAN KEGIATAN PENGABDIAN

\begin{tabular}{|c|c|c|c|}
\hline \multirow[t]{2}{*}{ No } & \multicolumn{3}{|c|}{ Tahapan Kegiatan } \\
\hline & Kegiatan & $\begin{array}{c}\text { Penanggung } \\
\text { jawab }\end{array}$ & Keterangan \\
\hline 1 & $\begin{array}{l}\text { Pengurusan izin dan } \\
\text { kerja sama }\end{array}$ & $\begin{array}{l}\text { Mitra (Ketua } \\
\text { RT 04 RW } \\
\text { 04, ketua } \\
\text { majelis } \\
\text { ta'lim, } \\
\text { Kepala } \\
\text { Sekolah TK/ } \\
\text { Paud } \\
\text { Raudhatul } \\
\text { Athfal An- } \\
\text { Nashr) }\end{array}$ & $\begin{array}{l}\text { Subyek } \\
\text { dimintai } \\
\text { kesediaan }\end{array}$ \\
\hline 2 & $\begin{array}{l}\text { Pendataan dan } \\
\text { penjaringan subyek }\end{array}$ & $\begin{array}{l}\text { Mitra (Ketua } \\
\text { RT 04 RW } \\
\text { 04, ketua } \\
\text { majelis } \\
\text { ta'lim, } \\
\text { Kepala } \\
\text { Sekolah TK/ } \\
\text { Paud } \\
\text { Raudhatul } \\
\text { Athfal An- } \\
\text { Nashr) }\end{array}$ & $\begin{array}{l}\text { Subyek } \\
\text { dimintai } \\
\text { kesediaan }\end{array}$ \\
\hline 3 & $\begin{array}{l}\text { Edukasi dan } \\
\text { penyuluhan tentang } \\
\text { gejala gangguan } \\
\text { kesehatan salah } \\
\text { satunya PTM }\end{array}$ & Tim & $\begin{array}{l}\text { Melibatkan } \\
\text { narasumber } \\
\text { sebagai } \\
\text { pembicara }\end{array}$ \\
\hline 4 & $\begin{array}{l}\text { Sesi diskusi atas } \\
\text { pemaparan materi } \\
\text { oleh narasumber }\end{array}$ & $\begin{array}{l}\text { Tim dan } \\
\text { mitra }\end{array}$ & $\begin{array}{l}\text { Disupervisi } \\
\text { oleh tim, mitra } \\
\text { ikut } \\
\text { berpartispasi } \\
\text { aktif }\end{array}$ \\
\hline 5 & $\begin{array}{l}\text { Edukasi dan } \\
\text { penyuluhan cara } \\
\text { mengatasi PTM } \\
\text { dengan mengikuti } \\
\text { gaya hidup } \\
\text { sehat :(pemanfaatan } \\
\text { buah naga yang kaya } \\
\text { antioksidan yang bisa } \\
\text { digunakan sebagai } \\
\text { pewarna alami } \\
\text { sebagai bahan } \\
\text { makanan,minuman } \\
\text { dan kosmetik), efek } \\
\text { berbahaya pewarna } \\
\text { buatan }\end{array}$ & Tim & $\begin{array}{l}\text { Melibatkan } \\
\text { narasumber } \\
\text { sebagai } \\
\text { pembicara }\end{array}$ \\
\hline 6 & $\begin{array}{l}\text { Sesi diskusi atas } \\
\text { pemaparan materi } \\
\text { oleh narasumber }\end{array}$ & $\begin{array}{l}\text { Tim dan } \\
\text { mitra }\end{array}$ & $\begin{array}{l}\text { Disupervisi } \\
\text { oleh tim, mitra } \\
\text { terlibat aktif }\end{array}$ \\
\hline 7 & $\begin{array}{l}\text { Pembagian booklet } \\
\text { sebagai panduan } \\
\text { pembuatan makanan, } \\
\text { minuman, dan } \\
\text { kosmetik dengan } \\
\text { metode sederhana } \\
\text { dari buah naga }\end{array}$ & Tim & $\begin{array}{l}\text { Sebagai } \\
\text { panduan bagi } \\
\text { mitra saat } \\
\text { melakukan } \\
\text { pengolahan } \\
\text { buah naga } \\
\text { menjadi } \\
\text { makanan, } \\
\text { minuman dan } \\
\text { kosmetik }\end{array}$ \\
\hline 8 & $\begin{array}{l}\text { Praktek pembuataan } \\
\text { puding buah naga } \\
\text { merah, es buah naga } \\
\text { merah }\end{array}$ & Tim & $\begin{array}{l}\text { Disupervisi } \\
\text { oleh tim, mitra } \\
\text { ikut terlibat } \\
\text { aktif }\end{array}$ \\
\hline
\end{tabular}




\begin{tabular}{|c|l|l|l|}
\hline 9 & $\begin{array}{l}\text { Sesi diskusi tentang } \\
\text { praktek pengolahan } \\
\text { buah naga merah } \\
\text { menjadi puding dan } \\
\text { es buah }\end{array}$ & $\begin{array}{l}\text { Tim dan } \\
\text { mitra }\end{array}$ & $\begin{array}{l}\text { Disupervisi } \\
\text { oleh tim dan } \\
\text { mitra } \\
\text { berpartisipasi } \\
\text { aktif }\end{array}$ \\
\hline 9 & $\begin{array}{l}\text { Praktek pembuatan } \\
\text { lipbalm dari buah } \\
\text { naga merah dengan } \\
\text { metode sederhana }\end{array}$ & Tim & $\begin{array}{l}\text { Dikoordinasi } \\
\text { oleh tim } \\
\text { dengan } \\
\text { partisipasi } \\
\text { mitra yang } \\
\text { aktif }\end{array}$ \\
\hline 10 & $\begin{array}{l}\text { Sesi diskusi tentang } \\
\text { praktek pembuatan } \\
\text { lipbalm }\end{array}$ & $\begin{array}{l}\text { Tim dan } \\
\text { mitra }\end{array}$ & $\begin{array}{l}\text { Mitra terlibat } \\
\text { aktif dan tahap } \\
\text { ini disupervisi } \\
\text { oleh tim }\end{array}$ \\
\hline 11 & $\begin{array}{l}\text { Pembagian form } \\
\text { Mitra } \\
\text { menyampaikan } \\
\text { kesan dan } \\
\text { pesan atas } \\
\text { kegiatan } \\
\text { pengabdian ini }\end{array}$ \\
\hline 12 & $\begin{array}{l}\text { Pengolahan makanan, } \\
\text { minuman dan } \\
\text { kosmetik dari buah } \\
\text { naga mandiri } \\
\text { sehingga dapat } \\
\text { mengikuti pola gaya } \\
\text { hidup sehat dan bisa } \\
\text { menyebarluaskan } \\
\text { pengetahuan ini }\end{array}$ & $\begin{array}{l}\text { Tim dan } \\
\text { mitra }\end{array}$ & $\begin{array}{l}\text { Menjamin } \\
\text { keberlanjutan } \\
\text { (sustainability) } \\
\text { program }\end{array}$ \\
& & \\
\hline
\end{tabular}

\section{BAB IV \\ HASIL DAN PEMBAHASAN}

Kegiatan pengabdian ini dilakukan pada dua mitra dengan waktu yang berbeda. Untuk wali murid dan guru TK/ PAUD Raudhatul Athfal An-Nashr Kampung Jati Parung Bogor dihadiri 21 peserta. Pada Majelis Ta'lim RT 04 RW 04 Kampung Jati Parung Bogor yang dihadiri 24 peserta. Upaya untuk menyelesaikan permasalahan yang dihadapi oleh mitra dalam mendukung program hidup sehat pada masyarakat adalah memberikan wawasan tentang buah naga merah sebagai buah yang mengandung antioksidan serta berfungsi sebagai pewarna alami. Buah naga merah ini dapat diolah sedemikian rupa sehingga menghasilkan makanan, minuman sehat serta kosmetik sederhana. Metode yang dilaksanakan adalah dengan memberikan materi tentang gangguan kesehatan salah satunya PTM, mengatasi PTM dengan mengikuti gaya hidup sehat, buah naga merah sebagai antioksidan zat pewarna alami.

Hasil dari tahapan kegiatan pengabdian ini akan dijelaskan di bawah ini:

- Edukasi dan penyuluhan tentang gejala gangguan kesehatan salah satunya PTM.

Pada sesi ini mitra mendapatkan materi tentang macam-macam penyakit PTM serta gejala-gejalanya. Keantusiasan peserta terlihat karena terjadi tanya jawab dengan narasumber

- Edukasi dan penyuluhan cara mengatasi PTM dengan mengikuti pola gaya hidup sehat.
Pada sesi ini diberikan materi pola gaya hidup sehat salah satunya dengan penerapan pola konsumsi makanan dan minuman yang sehat yang berasal dari buah naga merah yang kaya antioksidan dan merupakan pewarna alami. Selanjutnya dijelaskan juga efek pewarna buatan bagi tubuh yang banyak digunakan pada makanan dan kosmetik. Ibu-ibu peserta pengabdian banyak memberikan pertanyaan pada narasumber karena mendapatkan wawasan baru.

- Pembagian booklet

Sebagai panduan bagi mitra saat melakukan pengolahan buah naga menjadi makanan, minuman dan kosmetik dengan metode sederhana

- Praktek pembuataan puding buah naga merah, es buah naga merah.

Pada sesi ini mitra terlibat aktif dan antusias mengikuti cara pembuatan puding buah naga merah dan es buah naga merah. Mereka mengamati bahwa makanan dan minuman yang dibuat warnanya menjadi merah yang didapatkan dari pewarna alami buah naga merah. Jadi, tidak perlu menambahkan pewarna buatan untuk membuat makanan atau minuman menjadi merah. Pada saat praktek pembuatan makanan dan minuman ini terjadi aksi interaktif antara mitra dengan tim pengabdian.

- Praktek pembuatan lipbalm

Pada sesi ini, ibu-ibu mitra terlihat antusias dalam membuat lipbalm yang aman bagi tubuh dengan metode sederhana. Mereka menyadari ternyata buah naga merah bisa diolah menjadi suatu produk kosmetik yang tidak membutuhkan biaya besar dan tidak memerlukan waktu yang lama dalam membuatnya.

- Pembagian form

Evaluasi kegiatan dilakukan dengan cara membagikan form pada peserta pengabdian dimana peserta diminta keterangannya tentang kesan dan pesan acara ini. Hasil wawancara dan diskusi di akhir acara, peserta merasakan manfaat yang besar dari sosialisasi ini karena menambah wawasan baru tentang manfaat buah naga merah sebagai antioksidan dan pewarna alami yang dapat diolah untuk makanan, minuman sehat dan kosmetik sederhana. Dengan produk ini masyarakat dapat memenuhi gaya hidup sehat sehingga terhindar dari penyakit. 


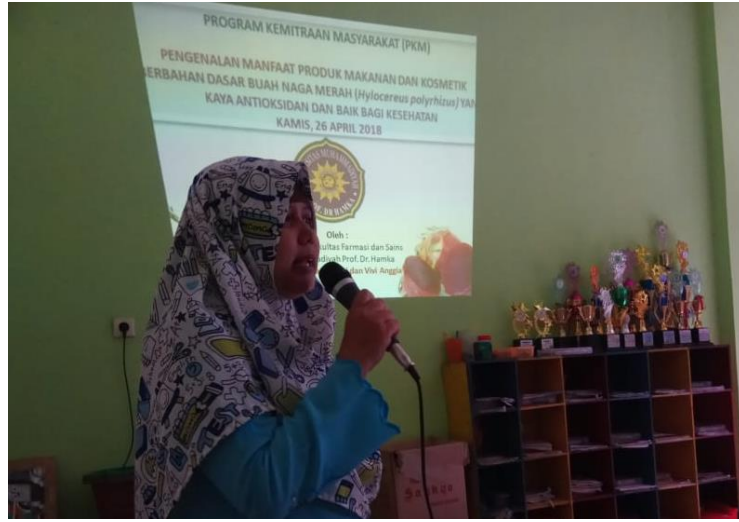

Gambar 1. Narasumber sedang memberikan materi pengabdian

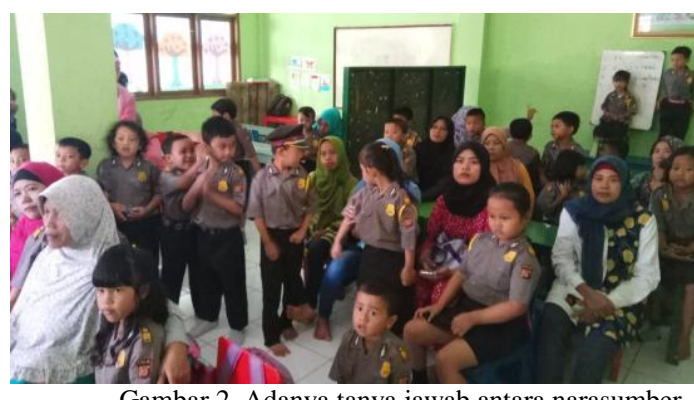

Gambar 2. Adanya tanya jawab antara narasumber dengan Ibu-ibu wali murid TK/ Paud Raudhatul Athfal An-Nashr Kampung Jati, Desa Parung

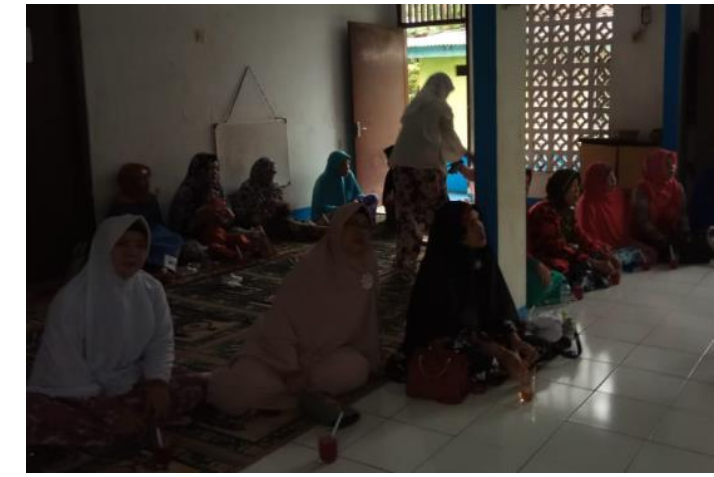

Gambar 3. ibu-ibu majelis ta'lim RT 004 RW 004 mendengarkan penjelasan dari narasumber

Pada kegiatan pengabdian ini diharapkan meningkatkan pengetahuan mitra dan masyarakat umum tentang gejala PTM, cara mengatasinya dengan mengikuti gaya hidup sehat. Pola hidup sehat ini dilakukan dengan mengkonsumsi olahan makanan dan minuman yang berasal dari buah naga merah, memakai kosmetik yang berasal dari buah naga merah karena buah naga merah merupakan zat antioksidan yang mengandung polifenol yang dibutuhkan oleh tubuh dan merupakan zat pewarna alami yang tidak berbahaya bagi tubuh. Pada pengabdian ini masyarakat juga mendapatkan wawasan tentang pewarna non alami yang dapat membahayakan tubuh. Masyarakat dapat didorong kreativitasnya untuk mempraktekkan pembuatan olahan makanan dan minuman serta kosmetik yang menggunakan buah naga sebagai bahan dasarnya. Manfaat lain yang dicapai dari program ini adalah membantu mitra untuk mengembangkan kemampuan dan ketrampilannya untuk memecahkan masalah (capacity building) untuk memilih makanan, minuman, dan kosmetik yang sehat sehingga dapat terhindar dari penyakit.

Keberlanjutan (sustainability) program secara mandiri dapat dipastikan dari rutinitas mitra dalam mempertahankan hidup sehat dengan mengurangi mengkonsumsi makanan siap saji dan tidak membeli kosmetik secara sembarangan. Keberhasilan dan keberlanjutan pengembangan program secara mandiri oleh mitra juga dapat dilihat dari besarnya motivasi dan kemauan mitra untuk menyebarluaskan pengetahuan tentang pewarna alami yang didapatkan dari buah naga merah serta dan pewarna buatan yang terdapat pada makanan, minuman, kosmetik yang dapat membahayakan tubuh kepada keluarga atau masyarakat umum, serta keaktifan mitra untuk melakukan pengolahan makanan, minuman dan kosmetik dari buah naga merah yang kaya antioksidan secara mandiri dengan menggunakan metode sederhana sesuai buku panduan yang telah dibagikan oleh tim. Setelah selesai program pada masyarakat mitra akan terbentuk sistem yang mampu menerapkan hasil dari pengabdian ini.

Evaluasi program dapat dilakukan dengan melihat parameter keberhasilan yang meliputi perubahan sikap dan perilaku secara konsisten yang ditunjukkan oleh mitra yaitu antusiame mitra dalam pengolahan makanan, minuman dan kosmetik secara mandiri, bertambahnya pemahaman dan pengetahuan mitra tentang pewarna alami dan pewarna buatan, mitra memiliki keterampilan untuk menghindari makanan atau pemakaian kosmetik yang mengandung pewarna buatan, lebih mengutamakan penggunaan pewarna alami terutama yang mengandung antioksidan yang berguna dalam tubuh sehingga mempertahankan hidup sehat untuk menghindari penyakit PTM (achievements).

Final outcomes yang diharapkan muncul dari program pengabdian masyarakat ini adalah mengurangi faktor resiko PTM karena dapat mengubah prilaku masyarakat agar mengkonsumsi olaham makanan sehat dan menggunakan kosmetik yang aman bagi tubuh. Terbentuknya kelompok masyarakat yang menyenangi menu makanan yang diolah dari bahan baku segar, tinggi serat (salah satunya dari buah naga), pemakaian kosmetik yang didapatkan dari pengolahan buah dalam negri.

Jika program pengabdian masyarakat ini dapat berjalan dengan baik, memberikan manfaat dan dampak positif bagi mitra, serta dinilai telah menghasilkan final outcomes seperti yang diharapkan, maka program pengabdian masyarakat 
ini dapat ditawarkan oleh pengusul kepada mitra kelompok masyarakat di daerah lain pada tahun berikutnya.

\section{V.KESIMPULAN}

Kegiatan pengabdian seperti ini sangat diperlukan untuk meningkatkan pemahaman dan pengetahuan tentang manfaat buah naga merah sebagai bahan yang mengandung antioksidan dan pewarna alami sehingga bisa diolah sedemikian rupa menjadi makanan dan minuman yang sehat dan kosmetik sederhana. Dengan mengikuti pola konsumsi dan pemakaian kosmetik ini diharapkan masyarakat akan terhindar dari berbagai penyakit, salah satunya PTM. Respon peserta terhadap kegiatan ini sangat tinggi. Peningkatan wawasan mengenai bahasan yang diberikan selama kegiatan pengabdian ini menyebabkan peserta bisa mengolah buah naga merah menjadi makanan dan minuman dan kosmetik sederhana. Untuk itu perlu dilakukan sosialisasi dan praktek lain dengan tema yang beragam

\section{UCAPAN TERIMA KASIH}

Terima kasih pada LPPM Universitas Muhammadiyah Prof DR Hamka yang telah mendanai kegiatan ini. Ucapan terima kasih juga pada masyarakat Kampung Jati, Parung, Bogor sebagai mitra kegiatan pengabdian ini.

\section{DAFTAR PUSTAKA}

[1] Kementrian Kesehatan, R. (2011) Penerapan Pola Konsumsi Makanan dan Aktivitas Fisik Untuk mencegah Penyakit Tidak Menular, Kementrian Kesehatan RI. Available at: http://gizi.depkes.go.id/download/Pedoman Gizi/STRANAS kt penganta.pdf-gabung.pdf.

[2] M.M.A, N., A, O., F, A. H., Ghazali, M. and Dek, P. (2012) 'Antibacterial property of Hylocereus polyrhizus and hylocereus undatus peel extracts', International Food Research Journal, 19, pp. 59-66. Available at: www.ifrj.upm.edu.

[3] Omidizadeh, A., Yusof, R. M., Roohinejad, S., Ismail, A., Bakar, M. Z. A. and Bekhit, A. E. A. (2014) 'Anti-diabetic activity of red pitaya (hylocereus polyrhizus) fruit', $R S C$ Advances. Royal Society of Chemistry, 4(November), pp. 62978-62986. doi: 10.1039/C4RA10789F.

[4] Rebecca, O. P. S., Boyce, A. N. and Chandran, S. (2010) 'Pigment identification and antioxidant properties of red dragon fruit ( Hylocereus polyrhizus )', African Journal of Biotechnology, 9(10), pp. 1450-1454. Available at: www.academicjournals.org/AJB.

[5] Republik Indonesia, B. P. dan P. K. D. K. (2008) Riset Kesehatan Dasar (RISKESDAS) 2007. Jakarta. Available at: https://www.k4health.org/sites/default/files/laporanNasional Riskesdas 2007.pdf.

[6] Republik Indonesia, B. P. O. D. M. (2008) Peraturan Kepala Badan Pengawas Obat dan Makanan Republik Indonesia. Indonesia. Available at: jdih.pom.go.id. 